\title{
Estimation of Forest Fire Hazard Using Quantification 2 Method
}

\author{
Lapitan, Renato L.*, Ebisu, Nobuhiro*, Samarakoon, Lal ${ }^{* *}$ and Ogawa, Shigeru* \\ 数量化II類による林野火災危険地推定に関する研究
}

\author{
Renato L. LAPITAN・戎 信宏・L. SAMARAKOON・小川 滋
}

\begin{abstract}
Summary
Estimation of forest fire hazard is essential in order to protect and manage the forest against unforseen damage. This will invaluably and effectively support forest protection and planning of good judgment and charting correct future programs. Quantification 2 method carried out the analysis using data observed in a forest fire damage site in Japan. Data include aerial photographs, existing forest record files, topographic maps and Landsat Thematic Mapper (TM) data.

Estimation of sites considered as fire hazard area exhibited $87 \%$ accuracy when compared the outcome with the fire damage data. Fire hazard area classified into three-level classification, which defines high fire hazard, moderate fire hazard and light fire hazard, revealed that high fire hazard attributed an accuracy of $75 \%$, while estimate for moderate and light fire hazard showed $34 \%$ and $53 \%$ accuracy. Combining moderate and light fire hazard as low fire hazard, and high fire hazard into two-level classification, however, showed higher accuracy of $72 \%$ and $70 \%$, respectively.

Moreover, the study underscored the significance of Normalized Difference Vegetation Index (NDVI) and other TM band data in the estimate. Analysis disclosed that NDVI and TM band 4 could produce an accuracy of at least $62 \%$. Additional employment of TM data could further produce a relatively higher degree of agreeability. Reduction in volume of data is therefore possible while keeping the reliability of the estimates in order.
\end{abstract}

\section{Introduction}

Recognition of forest fire hazard is an important consideration in forest management and planning. Concern is essential to generate better knowledge in identifying possible fire danger zones so that strategies and measures can be undertaken to prevent or minimize its occurrence.

By definition, fire hazard would indicate the spread and diffusion of fire over a considerable area or space. The objectives of this paper include (a) application of quantification 2 method in estimating fire hazard area; (b) determination of the reliability of the method by comparing the estimated fire hazard with the observed fire damage data, and (c) examination of the significance of using NDVI and other TM data in fire hazard estimates.

キーワード：林野火災地, ランドサット TM データ, 数量化 III類, NDVI

Key words : Forest fire, Thematic Mapper, Quantification 2 method, NDVI

* Faculty of Agriculture, Ehime University. 愛媛大学農学部

** Nippon Koei Company, Ltd. 侏日本工営 


\section{The study area}

The study area covers a total of 1,215 hectares, set arbitrarily, that included about 391 hectares of forest land damage by fire (Fig. 1). The area represents a cross section of the different altitude which include shorelines to low lying sites, to hillsides extending up to mountainous regions. The analysis was conducted in forest area which was identified through interpretation of aerial photographs. This makes it an ideal place to study forest fire as a result of its recorded fire event in 1985 and make possible comparison between the observed damage and no damage localities with the estimated fire hazard.

\section{Materials}

\subsection{Topography}

A topographic map of the area was selected and chosen as the standard base map established with a mesh size of $30 \mathrm{~m} . \times 30 \mathrm{~m}$. using a scale of $1: 5000$. The mesh size was adopted in order to establish the same resolution with TM data. The scale was preferred for easy interpretation of physical features and boundaries.

Elevation data was generated from the topographic base map with average weighing used for interpolation. Fig. 2 shows the spatial distribution of elevation factor.

Subsequently, computer programs were developed to extract gradient and aspect following the two by two moving window depicting the elevation data. Aspect was calculated into eight directions including flat surface. Gradient was derived as $\tan \theta$ from 0 to 1.09 classified into six classes of fairly equal number of observations.

\subsection{Vegetation characteristics}

Vegetation classification was done through visual interpretation of aerial photographs cross-referenced with conventional maps and record files. Two sets of aerial photographs, taken in 1972 and in 1982, were gathered including maps and forest record files from Geographic Survey, Ministry of Construction and Ehime and Kagawa Prefecture Office. A total of four vegetation cover categories were established, namely: (1) hinoki (Chamaecyparis obtusa Sieb. et. Zucc.), (2) matsu (Pinus densiflora Sieb. et. Zucc.) of the evergreen forest type; (3) a mixture type of needleleaf and broad-leaved species, and (4) a mixture of hardwood species.

Forest density was defined into three levels, i.e. low, medium and high as adopted based on gathered forest management record files.

On the same account, stand age was independently drawn on the base map representing 10-category

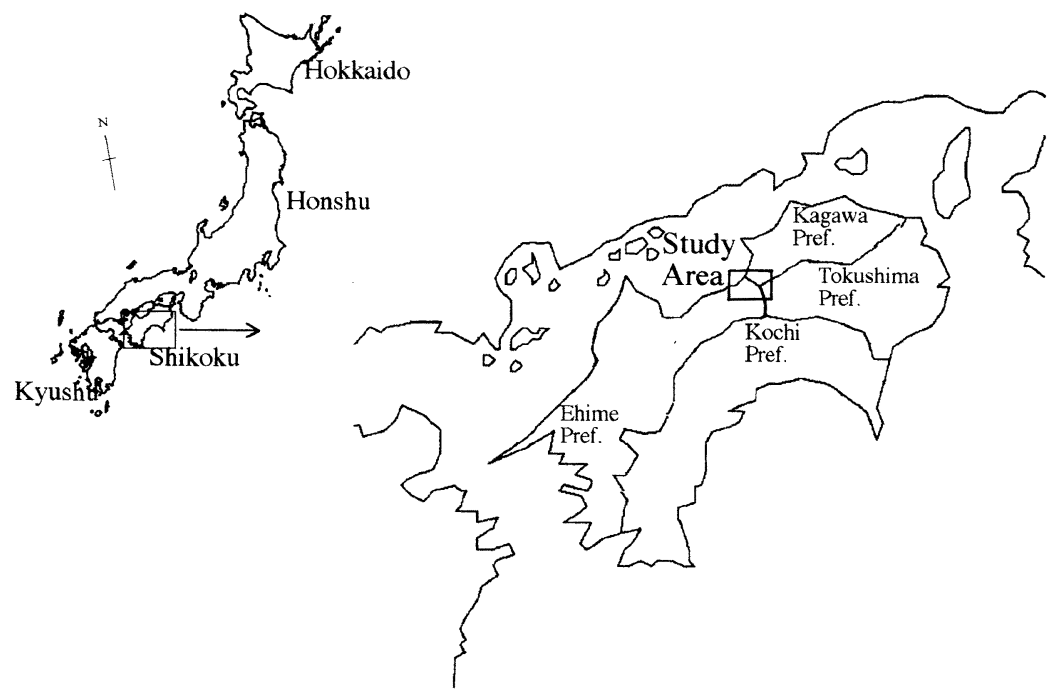

Fig. 1 Location of the study area 

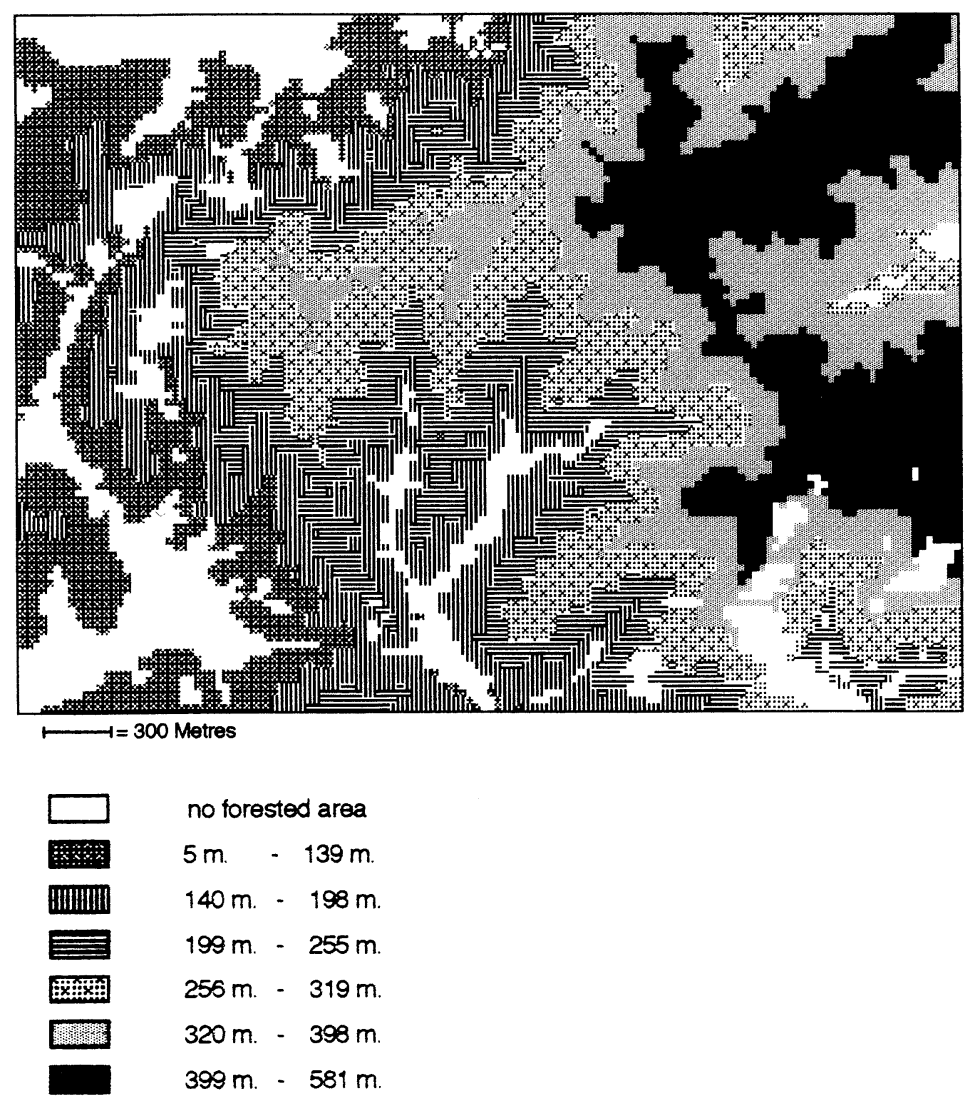

Fig. 2 Spatial distribution of elevation in the study area

classification as adopted from forest management record files, from the youngest 6 years old to 50 years old at an interval of 5 years, and above 50 years old trees.

\section{3 Landsat}

Landsat Thematic Mapper (TM) data, acquired before the fire (May 1984), were employed which were geometrically corrected and referenced to the same base map. Normalized Difference Vegetation Index (NDVI) was derived from the channel corresponding to the near infra-red (TM band 4) and red wavelengths (TM band 3) which resolves to (band 4-band 3 ) / (band $4+$ band 3 ) .

\section{4 The fire damage data}

A fire damage map was produced through visual interpretation of colored aerial photographs, taken just after the fire (February 1985), verified through field surveys and drawn on the base map. The sever- ity of fire damage was characterized into three levels : area totally burned and appeared dark brown to black on aerial photographs were considered severe damage; area where trees remain standing but with all crown damage and appeared brownish were classified as moderate damage; and sites where trees partially burned and appeared light brown in color on photographs were considered light damage.

\section{Method}

One inherent characteristic in spatial analysis is the presence of map-based data described in the form of discrete categories. Quantification 2 method $^{4)}$ was utilized to provide an analysis between a qualitative phenomenon (external criterion) with defined independent factors that can be qualitative or quantitative, or both. This method aims to differentiate among $k$ class on a set of independent variables and 
has the following objectives: (a) to find linear composites of $n$ independent variables while maximizing the between groups and minimize the within group variations; (b) determine which of the independent variables contribute significantly to the class discrimination; and (c) classify observations to the one of the $k$ classes.

The external criterion was set up based on the whole study area. Fire damage area, irrespective of severity level, was categorized as fire hazard while those outside the boundary were classified as no fire hazard. Vegetation cover, aspect, gradient, elevation, stand age, forest density and NDVI were considered explanatory variables.

\section{Results and Discussion}

The results of the analysis revealed that elevation, stand age and NDVI factors were strongly related to fire hazards as shown in Table 1. The fire hazard entity of the external criterion indicated a strong relation with the independent variables for cases with negative category weights. Positive weights would imply a relation with the no fire hazard entity. Elevation, particularly at high altitude, could have been influenced mainly by the strong local wind, which blew along the slope in an upward direction. Fire along the slopes could have caused the air to rise that might have enabled these winds to blew harder in the mountain. This would imply that planning in terms of protection and revegetation efforts would have to consider additional emphasis on these places. Also, protection need to be applied at low elevation places as possible ignition source. Stand age, particularly at middle-aged classes from 16 to 20 years old and 31 to 40 years old showed strong relation with fire hazard as they may have significant effect on the amount of surface accumulation of dried leaves, twigs and barks that in turn would provided ample fuel materials for fire. This result was considered as a general trend in middleaged classes and that protection measures should involve removal of ignitable fuels and that pruning and thinning would break continuity of fuel available for fire.

Contribution of other ground-based factors which have not had strong relation in the analysis were indispensable. Aspect could have been complimented by the general wind direction prevailing in the area which followed a west, southwest direction ${ }^{7}$. Vegetation like Hinoki, and mixtures of hardwoods and softwoods showed influence on fire hazard. Hinoki were artificially planted in places replacing dead matsu trees, whereas mixtures of hardwood and softwood exist naturally. The presence of dead trees in addition to bushes and shrubs may have served influence as available fuel materials. Low forest density may indicate presence of bushes and shrubs, and high density forest as available fuel materials. The relative effect of gradient showed influence on fire hazard. Steep gradient was considered as may be due to strong fire convection, however, from the results it was not clear as to the influence of low gradient.

These analysis considered was based on the statistical results. The influence of these factors were not proved by other statistical and physical methods. These therefore would suggest a need for further analysis. Nevertheless, these information are important to take account of in planning protection and prevention as well as undertaking revegetation programs.

NDVI, which was obtained through Landsat data, showed that high and low values indicated influenced on fire hazard. High values may be due to high activity of the vegetation. During senescence period, functional life of leaves, other plant organs as well as tissues tend to deteriorate that lead its internal cells to become dehydrated ${ }^{2}$. This would imply reduced moisture in vegetation that would favor the occurrence of fire. Low NDVI values may have indicated low activity of the vegetation which may include young trees, bushes and shrubs.

Calibration was done following the results generated in the quantification analysis. All the explanatory variables were utilized regardless of the magnitude of their coefficients. Utilizing category weights, feasible discriminant function was formulated and scores were estimated using observations obtained from these variables. These scores were later differentiated and classified as either fire hazard or no 
LAPITAN $\cdot$ EBISU $\cdot$ SAMARAKOON - OGAWA : Estimation of Forest Fire Hazard Using Quantification 2 Method

Table 1 Results of quantification 2 method for fire hazard analysis

\begin{tabular}{|c|c|c|c|c|}
\hline $\begin{array}{l}\text { Independent } \\
\text { Variable }\end{array}$ & Attributes & Category Weight & Range & Partial Corr. \\
\hline Vegetation & $\begin{array}{c}\text { Matsu } \\
\text { Hinoki } \\
\text { Mix } \mathrm{H} \text { and } \mathrm{S}^{*} \\
\text { Other } \mathrm{H}^{* *}\end{array}$ & $\begin{array}{r}0.0470 \\
-0.2115 \\
-0.4103 \\
0.1891 \\
\end{array}$ & 0.5995 & 0.1256 \\
\hline Aspect & $\begin{array}{c}\text { North } \\
\text { Northeast } \\
\text { East } \\
\text { Southeast } \\
\text { South } \\
\text { Southwest } \\
\text { West } \\
\text { Northwest } \\
\text { Flat }\end{array}$ & $\begin{array}{r}-0.2234 \\
0.2278 \\
0.0940 \\
0.0604 \\
0.0516 \\
-0.0145 \\
0.0828 \\
-0.1127 \\
-0.3313 \\
\end{array}$ & 0.5592 & 0.0948 \\
\hline Gradient $(\tan \theta)$ & $\begin{array}{l}0-0.36 \\
0.37-0.49 \\
0.50-0.59 \\
0.60-0.69 \\
0.70-0.78 \\
0.79-1.09 \\
\end{array}$ & $\begin{array}{r}-0.1058 \\
0.0034 \\
0.0205 \\
0.0618 \\
0.0428 \\
-0.0348 \\
\end{array}$ & 0.1676 & 0.0379 \\
\hline Elevation (m.) & $\begin{array}{r}5-139 \\
140-198 \\
199-255 \\
256-319 \\
320-398 \\
399-581 \\
\end{array}$ & $\begin{array}{r}-0.4219 \\
0.5625 \\
0.6879 \\
0.3253 \\
-0.4378 \\
-0.7195 \\
\end{array}$ & 1.4074 & 0.3476 \\
\hline Stand Age (yrs.) & $\begin{array}{c}6-10 \\
11-15 \\
16-20 \\
21-25 \\
26-30 \\
31-35 \\
36-40 \\
41-45 \\
46-50 \\
51 \text { and above } \\
\end{array}$ & $\begin{array}{r}0.3765 \\
0.4206 \\
-0.9231 \\
0.2546 \\
0.2047 \\
-1.1140 \\
-0.9447 \\
0.7277 \\
0.2429 \\
0.0136 \\
\end{array}$ & 1.8417 & 0.3736 \\
\hline Forest Density & $\begin{array}{c}\text { Low } \\
\text { Medium } \\
\text { High } \\
\end{array}$ & $\begin{array}{r}-0.1037 \\
0.0863 \\
-0.8752 \\
\end{array}$ & 0.9615 & 0.1476 \\
\hline $\mathrm{NDVI}^{* * *}$ & $\begin{array}{r}-0.0526-0 \\
0.0001-0.2 \\
0.2001-0.3 \\
0.3001-0.4 \\
0.4001-0.5 \\
0.5001-0.6 \\
\end{array}$ & $\begin{array}{r}-0.9755 \\
0.5158 \\
0.2675 \\
-0.0077 \\
-0.5993 \\
-1.2582 \\
\end{array}$ & 1.7741 & 0.2037 \\
\hline $\begin{array}{l}\text { Dependent } \\
\text { Variable }\end{array}$ & Attributes & \multicolumn{3}{|c|}{ Mean } \\
\hline Fire Hazard & $\begin{array}{l}\text { Fire Hazard } \\
\text { No Fire Hazard }\end{array}$ & \multicolumn{3}{|c|}{$\begin{array}{r}-0.3978 \\
0.7143\end{array}$} \\
\hline
\end{tabular}

* $\quad$ Mixed Hardwoods and Softwoods

** Other Hardwoods

*** Normalized Difference Vegetation Index 
fire hazard using the discriminant score obtained in the result. To determine the accuracy, a comparison was made between the estimated fire hazard and fire damage data. The resulting residual surface is shown in Fig. 3 and the confusion matrix is summarized in Table 2. It was found that the accuracy of estimating fire hazard is about $87 \%$. The $13 \%$ misclassification could have been a result of strong influence by elevation. A $65 \%$ accuracy was obtained for no fire hazard estimate.

Analysis was carried out to examine the levels of fire severity. The external criterion was set up into three-level fire hazard classification; i.e. high, moderate, and light fire hazard. High fire hazard was characterized as those sites that concur with the established severe damage area, while moderate and light fire hazard correspond to moderate and light damage area, respectively. The explanatory variables employed were the same as those carried out in the preceding analysis.

Results disclosed that stand age, elevation, NDVI factor and aspect indicated a strong influence. A similar explanation could be offered as in the preceding analysis.

The accuracy of estimating high fire hazard was found to be $75 \%$ as shown in Table 3. However, a lesser degree of agreement was generated for moderate and light fire hazard having $34 \%$ and $53 \%$, respectively. The low accuracy could have been due to misinterpretation of fire severity levels in aerial photographs. Though verified through ground survey,

Table 2 Cell count between the observed fire damage area, and estimated fire hazard and no fire hazard area

\begin{tabular}{lcl}
\hline \multirow{2}{*}{ Variables } & \multicolumn{2}{c}{ Observed through Aerial } \\
\cline { 2 - 3 } & Photographs \\
\hline Fire Damage & No Fire Damage \\
\hline Fire Hazard & $3588(86.90 \%)$ & 2578 \\
\hline No Fire Hazard & 541 & $4836(65.23 \%)$ \\
\hline Total & 4129 & 7414 \\
\hline
\end{tabular}
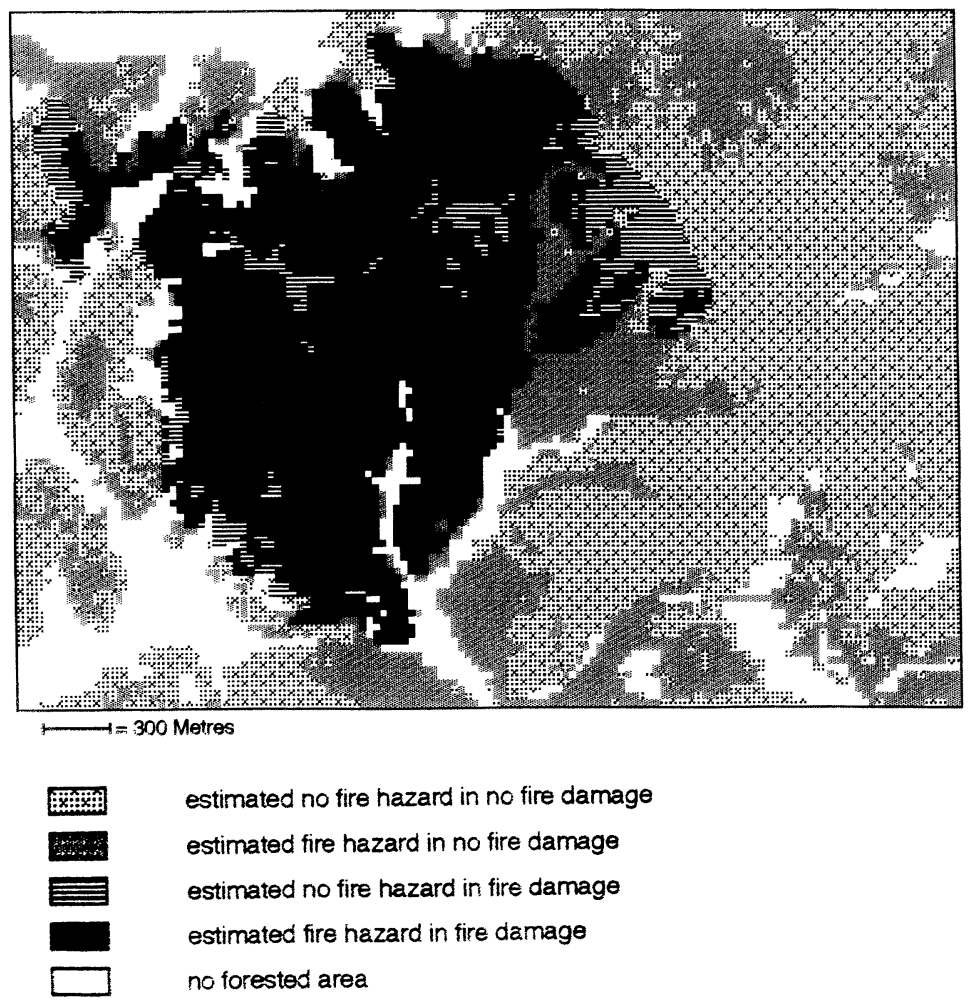

Fig. 3 Residual surface map of estimated fire hazard and observed fire damage 
error might have been committed in the subjective delineation particularly along the boundary of each level. Fig. 4 shows the residual surface map between the estimated three-level fire hazard classification and fire severity.

The misinterpretation of fire severity could be minimized using two-level fire hazard classification. The external criterion was categorized as high and low fire hazard. High fire hazard would represent areas considered as severe damage, while low fire hazard would describe the combination of moderate and light damage area. The same explanatory variables were used as in three-level classification.

The results indicated that factors which exert strong influence were found to be in agreement with those effecting fire hazard in three-level classification. However, a high degree of agreement was generated with $75 \%$ for high fire hazard, and $65 \%$ for low fire hazard as shown in Table 4.

Application of NDVI have been found with increasing popularity and usefulness. Investigation of
NDVI was conducted in relation to green biomass production (JENSEN et al. 19905) ; SADER and JOYCE 19889); and TUCKER et al. 1985 ${ }^{10)}$ ) ; yield modeling (ASHCROFT 1990) ${ }^{1)}$; grassland biomass production (KANEMASU et al. 1990) ${ }^{6}$ ) and in citrus orchard production (GILBERT and MELIN 1990) ${ }^{3)}$. Popularity could be attributed to: its high 'correlation with biophysical parameters, reduces the volume of data to

Table 3 Cell count between observed fire severity level and estimated three-level fire hazard classification

\begin{tabular}{lccc}
\hline \multirow{2}{*}{ Variables } & \multicolumn{3}{c}{ Observed Fire Severity Level } \\
\cline { 2 - 4 } & $\begin{array}{c}\text { Severe } \\
\text { Damage }\end{array}$ & $\begin{array}{c}\text { Moderate } \\
\text { Damage }\end{array}$ & $\begin{array}{c}\text { Light } \\
\text { Damage }\end{array}$ \\
\hline $\begin{array}{l}\text { High Fire } \\
\text { Hazard }\end{array}$ & $\begin{array}{c}1050 \\
(74.68 \%)\end{array}$ & 769 & 173 \\
\hline $\begin{array}{l}\text { Moderate Fire } \\
\text { Hazard }\end{array}$ & 160 & $\begin{array}{c}633 \\
(33.92 \%)\end{array}$ & 233 \\
\hline $\begin{array}{l}\text { Light Fire } \\
\text { Hazard }\end{array}$ & 196 & 465 & 450 \\
\hline Total & 1406 & 1867 & 856 \\
\hline
\end{tabular}

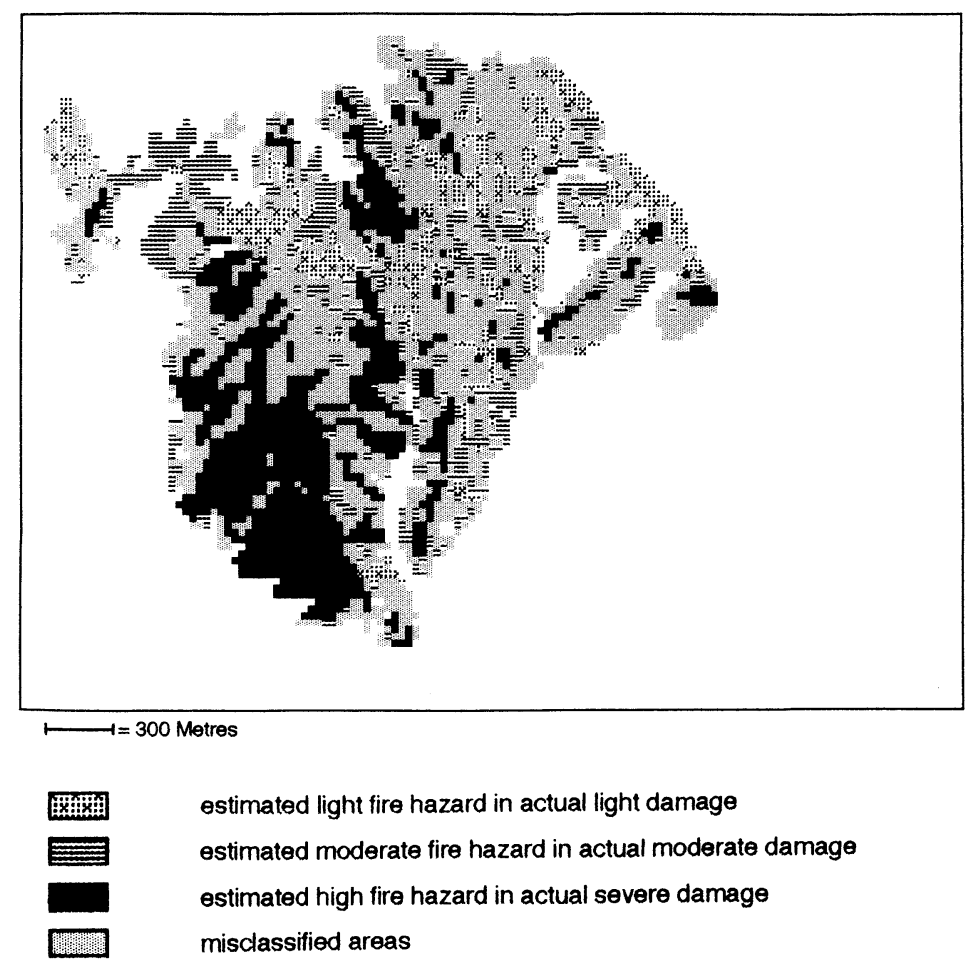

Fig. 4 Residual surface map of estimated three-level fire hazard classification, and observed fire severity level 
a single channel, and the convenience with which to incorporate into mathematical models for its semicontinuous nature of the value ${ }^{9}$.

The significance of utilizing other TM data, bands $3,4,5$ and 7 as well as their corresponding ratios : $3 / 4,3 / 5,3 / 7,4 / 5,4 / 7$ and $5 / 7$ were employed in addition to NDVI. These TM bands were applied as it were the channels available during the time of the study.

Initially, all these TM bands, band ratios and NDVI were utilized as group 1. Ground-based factors, which in the earlier analysis were found to be highly correlated were statistically compared with individual TM bands and band ratios. Results of the comparison is shown in Table 5 and were then utilized as group 2, including NDVI which was earlier found to be similarly significant. Accuracy of estimate using group 1 variables indicated $69 \%$ for fire hazard and $65 \%$ for no fire hazard area as shown in Table 6. Application of group 2 variables demonstrated an accuracy of $66 \%$ for fire hazard and $67 \%$ for no fire hazard. NDVI and TM band 4, which

Table 4 Cell count between the observed fire severity level, and estimated two-level fire hazard classification

\begin{tabular}{lcc}
\hline \multirow{2}{*}{ Variables } & \multicolumn{2}{c}{ Observed Fire Severity level } \\
\cline { 2 - 3 } & $\begin{array}{c}\text { Severe } \\
\text { Damage }\end{array}$ & $\begin{array}{c}\text { Combine Moderate } \\
\text { and Light Damage }\end{array}$ \\
\hline $\begin{array}{l}\text { High Fire } \\
\text { Hazard }\end{array}$ & $\begin{array}{c}1050 \\
(74.68 \%)\end{array}$ & 942 \\
\hline $\begin{array}{l}\text { Low Fire } \\
\text { Hazard }\end{array}$ & 356 & $\begin{array}{c}1781 \\
(65.43 \%)\end{array}$ \\
\hline Total & 1406 & 2723 \\
\hline
\end{tabular}

appeared as group 3, were found to be highly significant from among the various combinations of variables in group 2. Results indicated an accuracy of $63 \%$ and $64 \%$ for fire hazard and no fire hazard, respectively.

Similar analysis was carried out using three-level fire hazard classification. All groups registered an accuracy of at least $66 \%$ for high fire hazard as shown in Table 7. However, low accuracy were generated for moderate and light fire hazard, for reason as stated in the earlier results. Minimizing this effect, examination using two-level classification revealed a high degree of agreement for all groups. Estimation showed an average accuracy of $66 \%$ for high fire hazard and $62 \%$ for low fire hazard as indicated in Table 8.

\section{Conclusion}

Examination of spatial variables using quantification 2 method proved valuable and appropriate in fire hazard estimates. Remote sensing provided an additional source of information, while aerial photographs and ground-based information complimented the fire damage survey.

The estimates produced in the examination is specific to the study area. The influence of elevation and aspect was particularly strong owing to the effect of strong wind that prevailed over the area at the time of fire. Other ground-based factors contributed their significance as well. Hence, application of fire hazard reduction measures to serve the purpose require decisions based on careful evaluation and planning. By taking relevant factors into account, good judgment in such decisions can be constantly

Table 5 Partial correlation results between individual TM bands, band ratios, and ground-based data

\begin{tabular}{|c|c|c|c|c|c|c|c|c|c|c|}
\hline \multirow{2}{*}{$\begin{array}{l}\text { Ground-based } \\
\text { Variables }\end{array}$} & \multicolumn{4}{|c|}{ TM Bands } & \multicolumn{6}{|c|}{ TM Band ratios } \\
\hline & 3 & 4 & 5 & 7 & $3 / 4$ & $3 / 5$ & $3 / 7$ & $4 / 5$ & $4 / 7$ & $5 / 7$ \\
\hline Vegetation & 1 & 3 & 2 & 0 & 2 & 3 & 1 & 0 & 0 & 0 \\
\hline Aspect & 3 & 2 & 1 & 0 & 2 & 3 & 1 & 0 & 0 & 0 \\
\hline Gradient & 0 & 2 & 3 & 1 & 0 & 2 & 3 & 1 & 0 & 0 \\
\hline Elevation & 2 & 3 & 1 & 0 & 2 & 3 & 1 & 0 & 0 & 0 \\
\hline Age & 3 & 2 & 1 & 0 & 3 & 2 & 0 & 0 & 0 & 1 \\
\hline Forest Density & 3 & 2 & 0 & 1 & 2 & 3 & 1 & 0 & 0 & 0 \\
\hline
\end{tabular}

3: High. 2: Medium. 1: Low. 0: Very Low. 
Table 6 Cell count between the observed fire damage area, and estimated fire hazard and no fire hazard area using satellite data

\begin{tabular}{lccc}
\hline \multirow{2}{*}{ Variables } & \multicolumn{2}{c}{$\begin{array}{l}\text { Observed through Aerial } \\
\text { Photographs }\end{array}$} \\
\cline { 3 - 4 } & & Fire Damage & No Fire Damage \\
\hline \multirow{2}{*}{ Fire } & Group 1 & $2831(68.56 \%)$ & 2556 \\
Hazard & Group 2 & $2739(66.34 \%)$ & 2478 \\
& Group 3 & $2606(63.11 \%)$ & 2657 \\
\hline \multirow{2}{*}{ No Fire } & Group 1 & 1298 & $4858(65.52 \%)$ \\
Hazard & Group 2 & 1390 & $4936(66.58 \%)$ \\
& Group 3 & 1523 & $4757(64.16 \%)$ \\
\hline
\end{tabular}

Group 1: TM Band 3,4,5,7, Band Ratios, NDVI.

Group 2: TM Band 3,4, Band Ratio 3/5, NDVI.

Group 3 : TM Band 4, NDVI.
Table 8 Cell count between the observed fire severity level, and estimated two-level fire hazard using satellite data

\begin{tabular}{lccc}
\hline \multirow{2}{*}{ Variables } & \multicolumn{2}{c}{ Observed Fire Severity level } \\
\cline { 3 - 4 } & & $\begin{array}{c}\text { Severe } \\
\text { Damage }\end{array}$ & $\begin{array}{c}\text { Combine Moderate } \\
\text { and Light Damage }\end{array}$ \\
\hline High & Group 1 & $932(66.29 \%)$ & 992 \\
Fire & Group 2 & $944(67.14 \%)$ & 1024 \\
Hazard & Group 3 & $939(66.79 \%)$ & 1025 \\
\hline Low & Group 1 & 474 & $1731(63.57 \%)$ \\
Fire & Group 2 & 462 & $1699(62.39 \%)$ \\
Hazard & Group 3 & 467 & $1698(62.36 \%)$ \\
\hline Group 1: TM Band 3,4,5,7, Band Ratios, NDVI. \\
Group 2: TM Band 3,4, Band Ratio 3/5, 4/7, NDVI. \\
Group 3: TM Band 4, NDVI.
\end{tabular}

Table 7 Cell count between observed fire severity level and estimated three-level fire hazard using satellite data

\begin{tabular}{|c|c|c|c|c|}
\hline \multicolumn{2}{|c|}{ Variables } & \multicolumn{3}{|c|}{ Observed Fire Severity Level } \\
\hline & & $\begin{array}{l}\text { Severe } \\
\text { Damage }\end{array}$ & $\begin{array}{l}\text { Moderate } \\
\text { Damage }\end{array}$ & $\begin{array}{l}\text { Light } \\
\text { Damage }\end{array}$ \\
\hline \multirow{3}{*}{$\begin{array}{l}\text { High Fire } \\
\text { Hazard }\end{array}$} & Group 1 & $\begin{array}{c}928 \\
(66.00 \%)\end{array}$ & 815 & 377 \\
\hline & Group 2 & $\begin{array}{c}946 \\
(67.28 \%)\end{array}$ & 745 & 273 \\
\hline & Group 3 & $\begin{array}{c}941 \\
(66.93 \%)\end{array}$ & 746 & 277 \\
\hline \multirow{3}{*}{$\begin{array}{c}\text { Moderate } \\
\text { Fire } \\
\text { Hazard }\end{array}$} & Group 1 & 245 & $\begin{array}{c}649 \\
(34.76 \%)\end{array}$ & 319 \\
\hline & Group 2 & 240 & $\begin{array}{c}572 \\
(30.64 \%)\end{array}$ & 319 \\
\hline & Group 3 & 247 & $\begin{array}{c}631 \\
(33.80 \%)\end{array}$ & 365 \\
\hline \multirow{3}{*}{$\begin{array}{l}\text { Light } \\
\text { Fire } \\
\text { Hazard }\end{array}$} & Group 1 & 233 & 403 & $\begin{array}{c}160 \\
(18.69 \%)\end{array}$ \\
\hline & Group 2 & 220 & 550 & $\begin{array}{c}264 \\
(30.84 \%)\end{array}$ \\
\hline & Group 3 & 218 & 490 & $\begin{array}{c}214 \\
(25.00 \%)\end{array}$ \\
\hline
\end{tabular}

Group 1: TM Band 3,4,5,7, Band Ratios, NDVI.

Group 2: TM Band 3,4, Band Ratio 3/5, 4/7, 5/7, NDVI.

Group 3: TM Band 4, NDVI.

applied.

The use of TM data showed a fairly high accuracy in the estimates. This would imply that in conditions were limited ground-based data exist, the use of Landsat data may prove useful as an alternative source of information. The results of group 2 and group 3 analyses indicated that it is possible to reduce the volume of data while keeping the accuracy of the estimation in a reliable order. It is worthy to note that NDVI and TM band 4 appeared highly significant, as group 3, in all analyses. NDVI indicated high correlation with age and aspect, and also age and aspect have strong relationship with fire hazard. Hence, NDVI could served as an important element in fire hazard estimation. NDVI served as an effective vegetation index measure in the study. This could 
invaluably assist in recognizing fire danger zones that would significantly contribute to effective revegetation planning and protection efforts. Utilizing ground data alone would indicate that vegetation proved significant in the estimates. Furthermore, the geographically strong influence of elevation and aspect could have contributed significantly towards the recognition of important factors in the estimates, not only of vegetation, but the general surface condition of the area like moisture content as well.

\section{References}

1) Ashcroft, P.M., Catt, J.A., Curran, P.J., Munden, J., and WEBSTER, R.: The relation between reflected radiation and yield on the Broadbalk winter wheat experiment. International Journal of Remote Sensing, 11(10) 1821-1836, 1990

2) Belward, A.S. and VAlenzuela, C.R. (editors) : Spectral characteristics of vegetation, soil and water in the visible, near-infrared and middle-infrared wavelengths. Remote Sensing and GIS for Resource Management in Developing Countries. Printed in Netherlands, 31-53, 1991

3) Gilbert, M.A., and MELin, J.: A simplified algorith$\mathrm{m}$ for the evaluation of frost-affected citrus. Application of Remote Sensing in Agriculture, edited by M.D. STEVEN and J.A. CLARK (London: Butterworth), 273
$-284,1990$

4) Hayashi, T., and Tsutomo, K.: Theory of Quantification and Data Analysis. Asakura Book Company. pp. 292, (in Japanese), 1982

5) Jensen, A., Lorenzen, B., OstergaArd, H., and HVELPLUND, E.K.: Radiometric estimation of biomass and nitrogen content of barley grown at different nitrogen levels. Int. Journal of Remote Sensing, 11(10) 1809-1820, 1990

6) Kanemasu, E.T., Demetriades-Shah, T.H. and Su, H. : Estimating grassland biomass using remotely sensed data. Application of Remote Sensing in Agriculture, M.D. STEVEN and J.A. ClARK (ed.) (London: Butterworth), 185-200, 1990

7) Lapitan, R., Samarakoon, L., Ebisu, N., Inoue, S., SATO, K., and OGAWA, S. : Automated spatial mapping and inventory system for analyzing forest firedamaged area. Proc. of the International Symposium in Integrated Forest Management Information Systems, Tsukuba, Japan, Oct. 13-18, 1991. 167-177, 1991

8) SADER, S.A. : Remote sensing investigations of forest biomass and change detection in tropical region. Proc. of the IUFRO 4.02.05, Finland, 1988

9) SADER S.A., and JoYCE, A.T.: Deforestation and trends in Costa Rica, 1940 and 1983. Biotropica 20, 1. 11-19, 1988

10) TuCKer, C.J. and MCMurTREY, J.E. : Temporal spectral measurements of corn and soybean crops. Photo. Eng. and Remote Sensing, 45(5) 643-653, 1979

(Received June 24, 1993)

\section{要旨}

林野火災危険地の推定は，予測できない林野火災に対し森林保護管理のために非常に重要であり，森林の保護，適正 な森林の管理計画, 将来の森林施業計画を行う上でも有効である。そこで地形図, 航空写真, 森林簿などのデータとラ ンドサット TM データを用いて数量化II類の解析により林野火災危険地推定を行った。これらのデータによる危険地の 推定では $87 \%$ 的中率で判別でき，また，被害地の燃焼程度を激，中，微の 3 段階に分類した判別では，それぞれの的 中率は激の箇所は $75 \%$, 中が $34 \%$, 微が $53 \%$ で, 中, 微の箇所の判別が良くないため, 中, 微の箇所をまとめて 2 段階 で判別した結果, 激が70\%, 微が72\%となった。さらに, NDVI 值と TM データのバンド值を用いて林野火災危険地の 判別を行った。バンド 4 と NDVI 值を用いた危険地推定および 2 段階の燃焼程度分類の判別とも $62 \%$ 上小的中率であ った。この推定法によっても地形情報, 植生情報, NDVI 值のデータを用いた推定に近い的中率が得られた。このこと から, データの得にくい対象地区においても NDVI 值などを用いることで, 林野火災危険地の推定が可能と考えられた。 